$1-1-1964$

\title{
Improvement cuttings in immature hardwood stands : yield income while increasing future sawtimber values
}

Roger W. Pease

Follow this and additional works at: https://researchrepository.wvu.edu/ wv_agricultural_and_forestry_experiment_station_bulletins

\section{Digital Commons Citation}

Pease, Roger W., "Improvement cuttings in immature hardwood stands : yield income while increasing future sawtimber values" (1964). West Virginia Agricultural and Forestry Experiment Station Bulletins. 492.

https://researchrepository.wvu.edu/wv_agricultural_and_forestry_experiment_station_bulletins/460 @ WVU. It has been accepted for inclusion in West Virginia Agricultural and Forestry Experiment Station Bulletins by an authorized administrator of The Research Repository @WVU. For more information, please contact ian.harmon@mail.wvu.edu. 
S0.

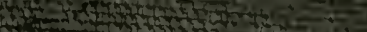

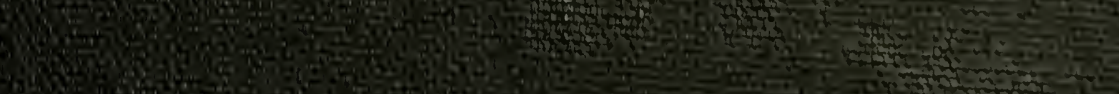
199.

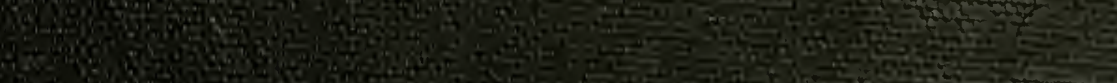

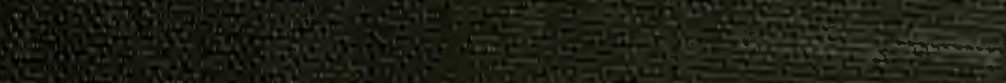

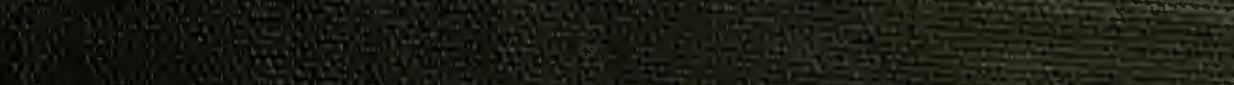
(10.0. 1.9. (3) (1)

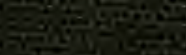
tiste $\cos 20$ 
Digitized by the Internet Archive in 2010 with funding from Lyrasis Members and Sloan Foundation 


\section{Improvement Cuttings in Immature Hardwood Stands-}

Yield Income While Increasing Future Sawtimber Values

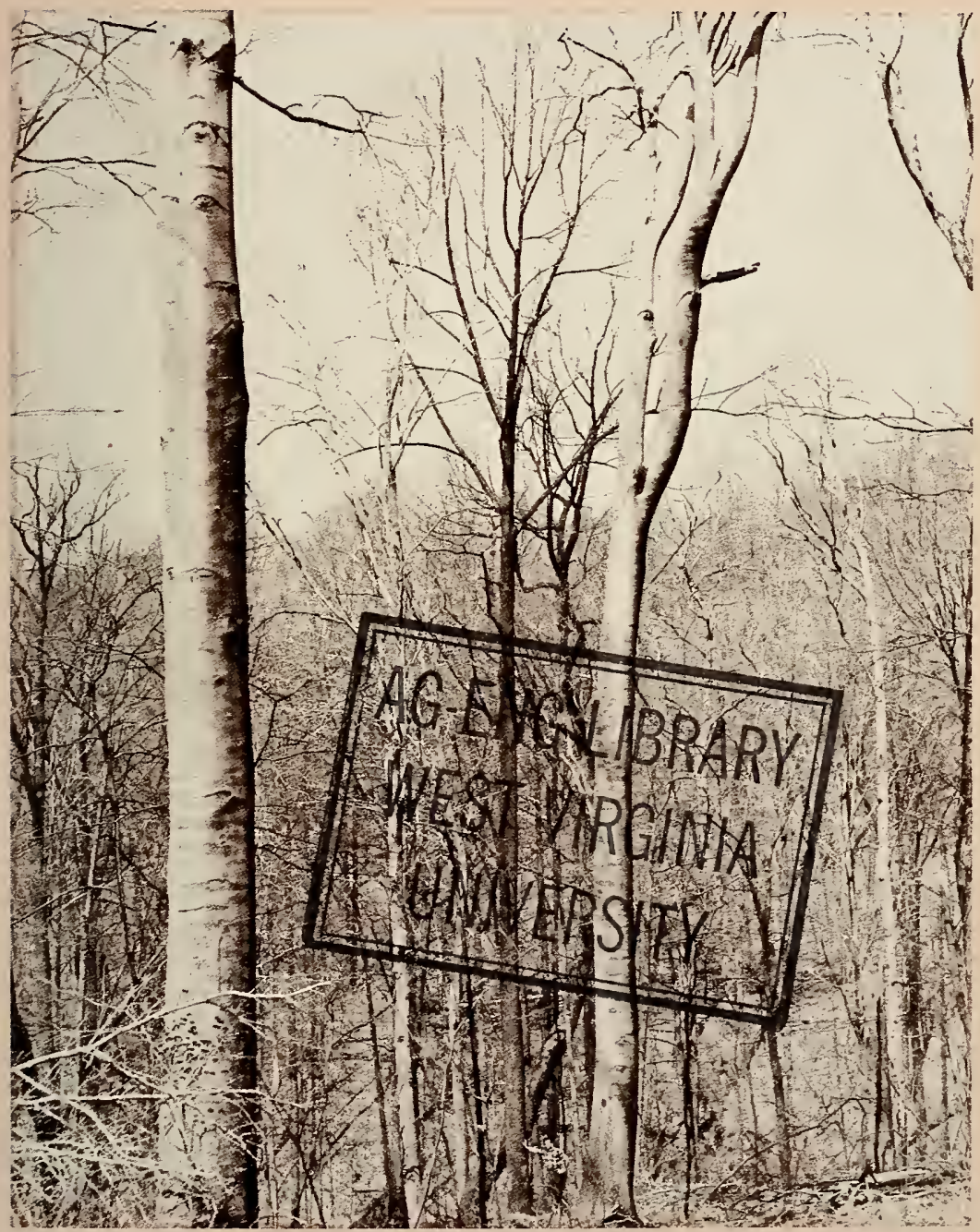




\section{THE AUTHOR}

Kenneth L. Carvell is Silviculturist in the Agricultural Experiment Station and Professor of Silviculture in the Division of Forestry, College of Agriculture, Forestry, and Home Economics.

Lithograpled in West Virginia Biggs-Johnston-Withrow, Beckley

West Virginia University Agricultural Experiment Station

College of Agriculture, Forestry, and Home Economics A. H. Vanlandingham, Director

MORGANTOWN 


\section{Improvement Cuttings in}

Immature Hardwood Stands-

\section{Yield Income While Increasing Future Sawtimber Values}

\section{Kenneth L. Carvell}

OST of the hardwood forests in the eastern United States are complex mixtures. In these forests trees of great and little commercial value grow side by side, competing with one another for survival. Oakhickory stands comprise the major forest area in West Virginia. These intricate mixtures dominate the drier slopes and ridges below an elevation of 3,000 feet, giving way where moisture is more abundant to stands of yellow-poplar and oak, or to pure yellow-poplar. Since stands where yellow-poplar forms a conspicuous part of the mixture are particularly characteristic of mountain coves, they are generally referred to as "cove hardwoods," even though the largest acreage of these valuable mixtures is found on moist, north- and east-facing slopes, not in the coves.

Stands of oak-hickory and cove hardwood types are generally evenaged, and have become established after heavy cuttings earlier in this century. Although the majority of these stands are not yet of sawtimber size, they contain many trees large enough for pulpwood, charcoal wood, or fuelwood. The demand for hardwood pulpwood and charcoal wood is gradually increasing in certain sections of this State. This suggests to many landowners the possibility of partial cuttings in their immature stands. Such cuttings could provide an immediate income, yet leave the most promising sawlog trees for future growth.

Selecting the proper trees to remove and the correct number to leave in each successive cutting can have a very important bearing on future stand development and affect the ultimate value of the sawtimber. The problems posed by such cuttings prompted a study by foresters of the West Virginia University Agricultural Experiment Station. Through experimental cuttings it was hoped that general rules or guides could be formulated which could be used by forest landowners and foresters when planning stand improvement operations. 


\section{Study Area}

To obtain information on the effect of partial cuttings on future stand development and the response of the remaining trees, study areas were set up in oak-hickory and cove hardwood stands at various locations throughout the State. One of these areas, established in the fall of 1949, consists of two plots, one (nearly an acre in size) which was to receive regular improvement cuttings at five-year intervals, and a control (one-half acre in area) that was to be left uncut for the purpose of comparison.

These plots are in Monongalia County on Chestnut Ridge, the westernmost portion of the Allegheny Mountains. The ground surface on these plots has a 20 per cent slope towards the north. The soil is a Dekalb stony loam. The site would be considered better-than-average for forest growth.

The stand selected for this pair of experimental plots is the yellowpoplar-white oak-northern red oak type, the most common cove type found in this State. The trees, primarily of sprout origin, were 15 years old in 1949. The species include yellow-poplar (Liriodendron tulipifera L.), northern red oak (Quercus rubra L.), white oak (Quercus alba L.), black oak (Quercus velutina Lam.), chestnut oak (Quercus prinus L.), scarlet oak (Quercus coccinea Muenchh.), black cherry (Prunus serotina Ehrh.), sassafras (Sassafras albidum [Nutt.] Nees), black locust (Robinia pseudoacacia L.), red maple (Acer rubrum L.), sugar maple (Acer saccharum Marsh.), bigtooth aspen (Populus grandidentata Michx.), cucumbertree (Magnolia acuminata L.), blackgum (Nyssa sylvatica Marsh.), butternut (Juglans cinerea L.), flowering dogwood (Cornus florida L.), and black birch (Betula lenta L.). Scattered hundred-year-old oak culls, left from previous logging operations, towered over the new sapling-sized stand (Figure 1). These culls, averaging four per acre, had created gaps in the young stand immediately beneath, and deformed those trees adjacent to their crowns.

\section{Principles Applied in Cutting}

The first improvement cutting was made in this plot in the fall of 1949. The objective was to favor the most valuable species, but only those stems with the straightest boles, free from rot or other visible defects. In each case, slow-growing trees were cut to make room for the faster-growing ones. The material that was removed was used for firewood in a nearby picnic area.

Species preference was based on the relative stumpage price for sawtimber. Well-formed black cherry, yellow-poplar, cucumbertree, 
sugar maple, northern red oak, black oak, and white oak were favored in that order. Stems of red maple, sassafras, bigtooth aspen, butternut, flowering dogwood, blackgum, and black birch were removed whenever they interfered with the development of the better species. Where large groups of desirable species stood close together, they were thinned out. Selection of the trees to remain was made on the basis of form, condition, and spacing. At the time of the first cutting, the old cull trees which towered over the new stand were girdled, since they had no value for any merchantable product, and were causing increasing amounts of damage to the new stand beneath.

The same principles were followed in the 1955 and 1960 cuttings. The ultimate goal of this series of improvement cuttings was to favor continually the 100 most-promising trees per acre, giving these trees every opportunity to develop rapidly into quality sawlogs. The need to reach this goal through a series of improvement cuttings rather than by just one heavy cut has been previously discussed by Besley (1941). In this paper it is stated that:

There are so many poor trees in present stands that only a very heavy cutting would be sufficient to get rid of all of the inferior trees. Heavy cuttings in the past have resulted in the exposure of large patches of soil which have dried out seriously afterwards. This brings in poor, slow growing species in the openings, and reduces the growth of the trees already present. Furthermore it increases the fire hazard. It is far better for the owner to make less severe cuttings more frequently and to give the trees which he leaves an opportunity to fill in the openings before he makes another cutting. Both markets and good forestry practice, then, call for a more gradual improvement of the stand under a plan extending over a long period.

In evaluating the bole of each tree, particular attention was given to the position of crooks, forks, and other deformities, in relation to the lengths of straight cuttings. Where deformities occurred at the base, or at sufficient height to allow a 12- or 16-foot log below and one or more logs above, they were not considered nearly as serious as deformities 6 to 10 feet above the ground, since the latter would drastically curtail the merchantable board foot, yield from the final tree (Figure 2).

In the first improvement cutting, multiple-stemmed trees were separated wherever necessary to improve stand density and spacing (Figure 3). At 15 years of age heartwood is not present in most stems, thus heartwood-rotting fungi cannot enter the remaining stem through the connected stump (Roth and Sleeth, 1939). In the second and third improvement cuttings, twin and multiple-stemmed trees were not usually separated-a policy of cutting or leaving all members of a clump was followed.

When trees of inferior species, or of poor form or condition, were too small for firewood, they were left in the stand unless they were 


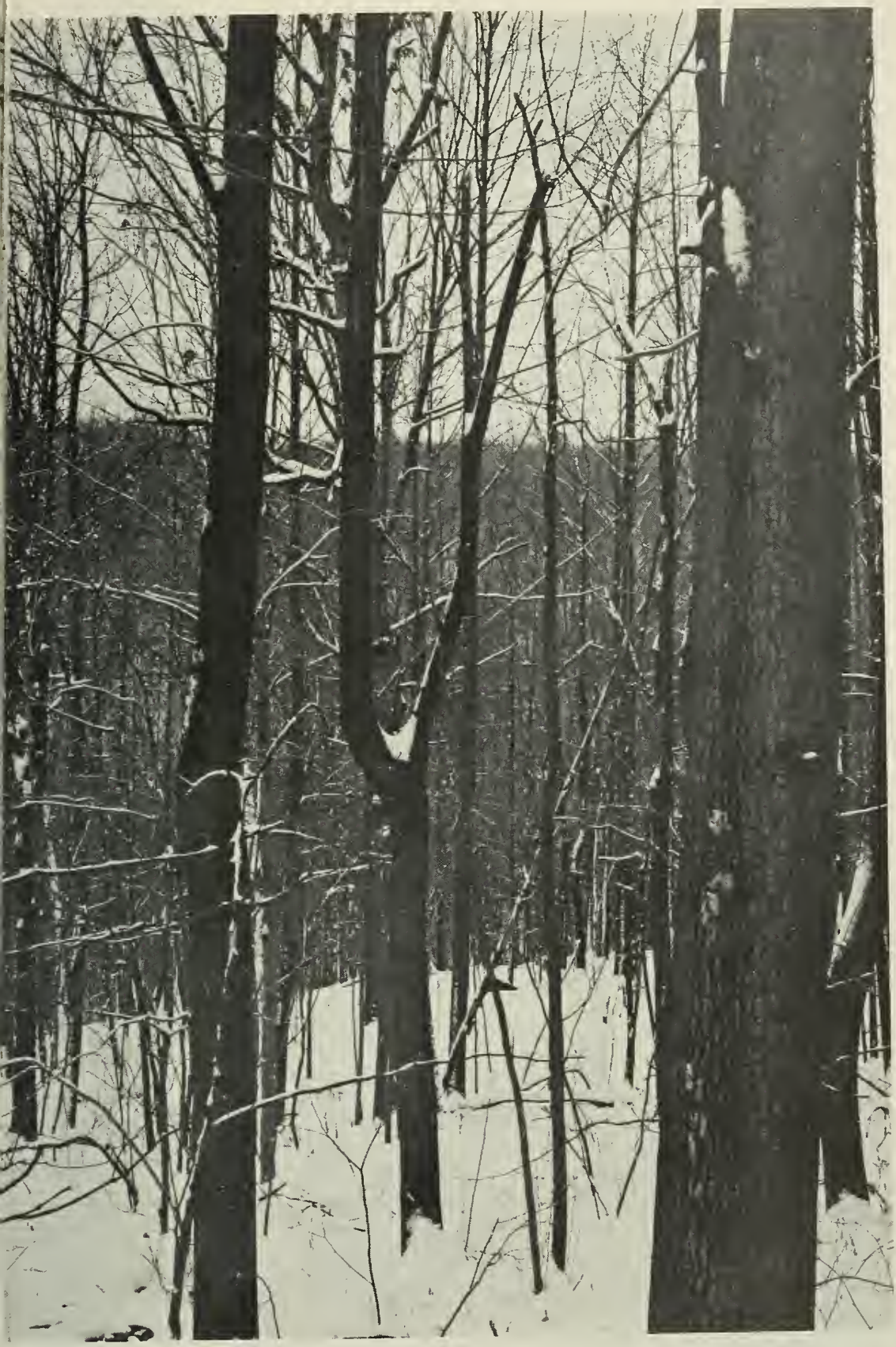

Figure 2. Two yellow-poplar on the control plot. The one on the left is potential sawtimber material, but the one on the right has a fork in a position which drastically reduces its value. 


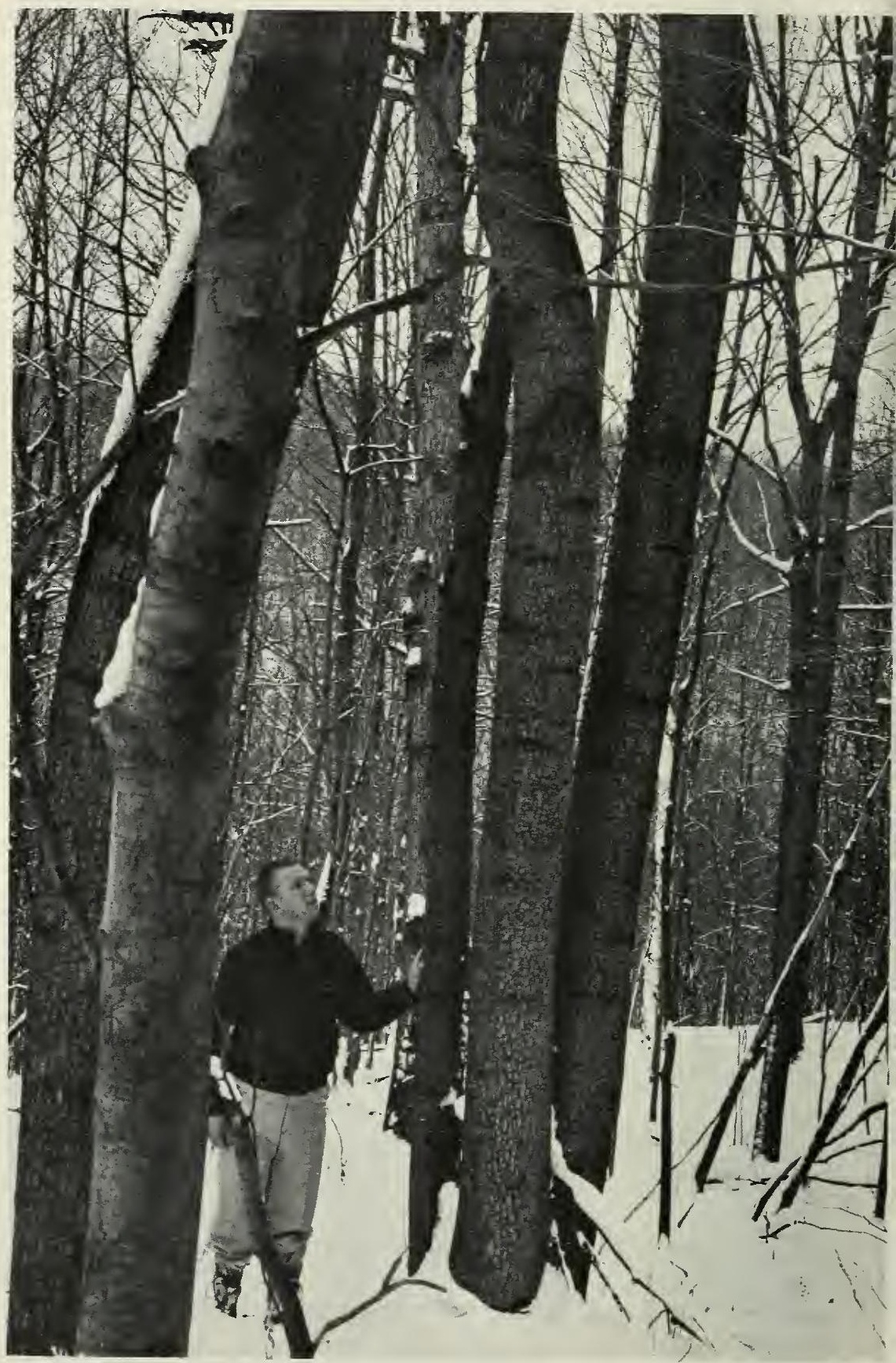

Figure 3. The control plot in 1963. Multiple-stemmed trees are abundant on this plot, resulting in poor spacing. 
actually harming future sawtimber trees. It was anticipated that these stems would respond to the increased light following the cuttings, and gradually reach merchantable size. Such trees would be taken out in later improvement cuttings, when a profit could be made from their removal and sale.

The present plan is to continue improvement cuttings at five-year intervals for two or more decades, and to cut the final sawlog crop at 50 or 60 years of age, depending on market conditions and the rate of stand development.

\section{Measurements}

The number of trees removed in each partial cutting, mortality between treatments, and changes in stand composition were determined before and after each cutting (Tables 1 and 2). The data in all tables exclude the old cull oaks which were left on the control plot.

Since a major basis for evaluating these cuttings is the species composition of the 100 trees per acre with the largest diameters, a breakdown of these trees by species was tabulated from the 1960 measurements. For the treated plot these represent the results of three cuttings in which the largest trees have continually been evaluated, and those with deformed or diseased boles removed. Thus, on the treated plot the 100 trees represent well-formed stems of unquestionable sawtimber potential (Figure 4).

The diameter breast high (d.b.h.) was computed before and after each cutting. Major objectives of a series of improvement cuttings are to increase the amount of usable wood fiber on the best trees, and to shorten the time needed to grow sawtimber-sized trees. The more rapid growth of the trees on the treated plot is attributed to the openings in the crown canopy which were created regularly around the crowns of the best trees (Figure 4). These openings allow the best trees to expand their crown area continually. This ever-increasing food-manufacturing center is reflected in the large amount of wood laid down on the bole annually. Table 4 presents the average diameters before and after each cutting during the 11-year period, 1949-1960.

Measurements were obtained on changes in basal area per acre for the 11-year period. Basal area is the total area in square feet of the cross section at breast height of all trees 1 inch in d.b.h. and larger in the stand. This figure, when expressed on a per acre basis, is useful in comparing the density of forest areas and their response to cutting. Table 5 gives changes in basal area for the treated plot and for the control. Table 6 presents the cord volume per acre before and after each cutting. 


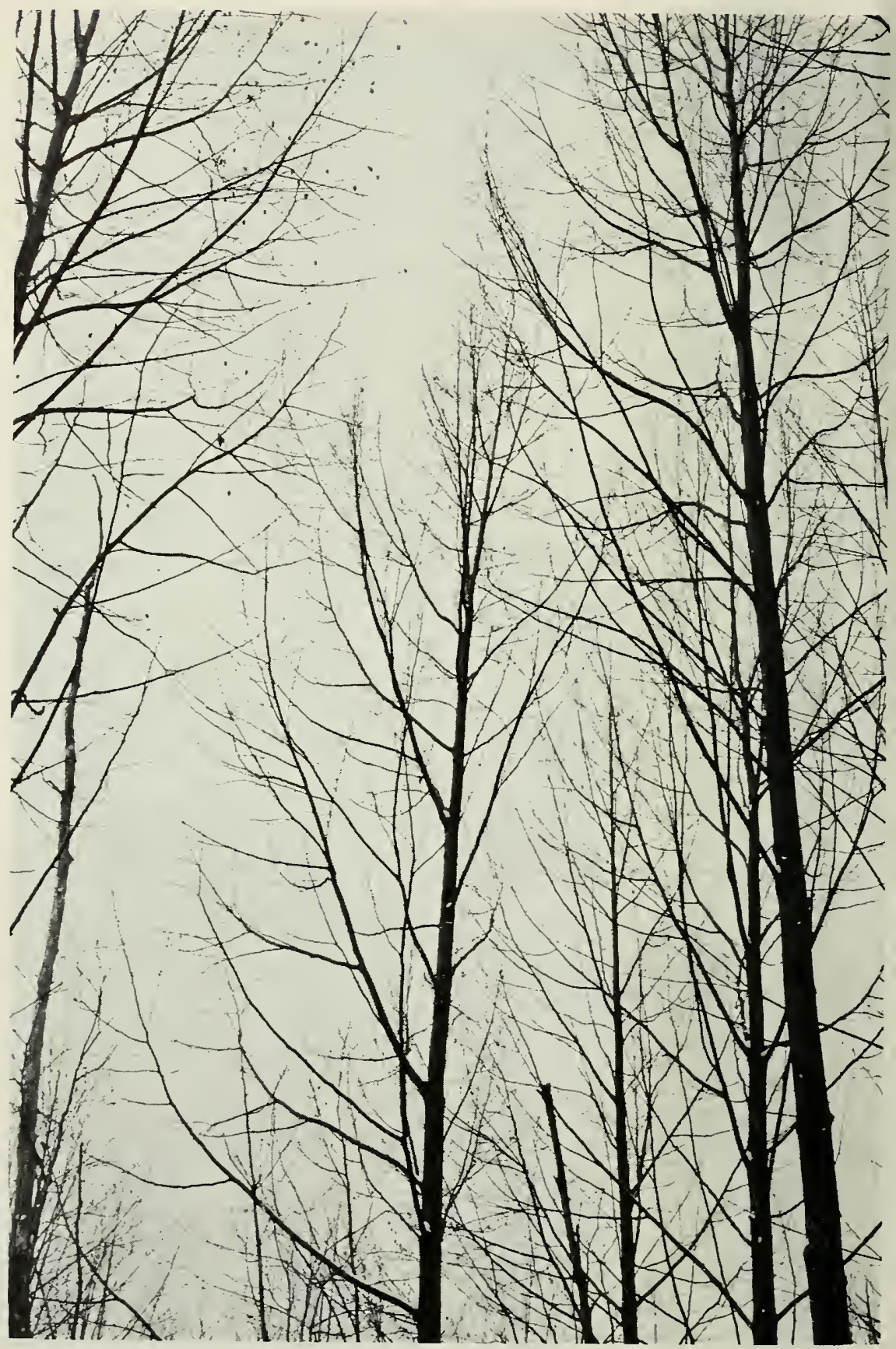

Figure 4-A. Crowns of the best trees on the treated plot were continually given room for expansion through cutting adjacent trees. 


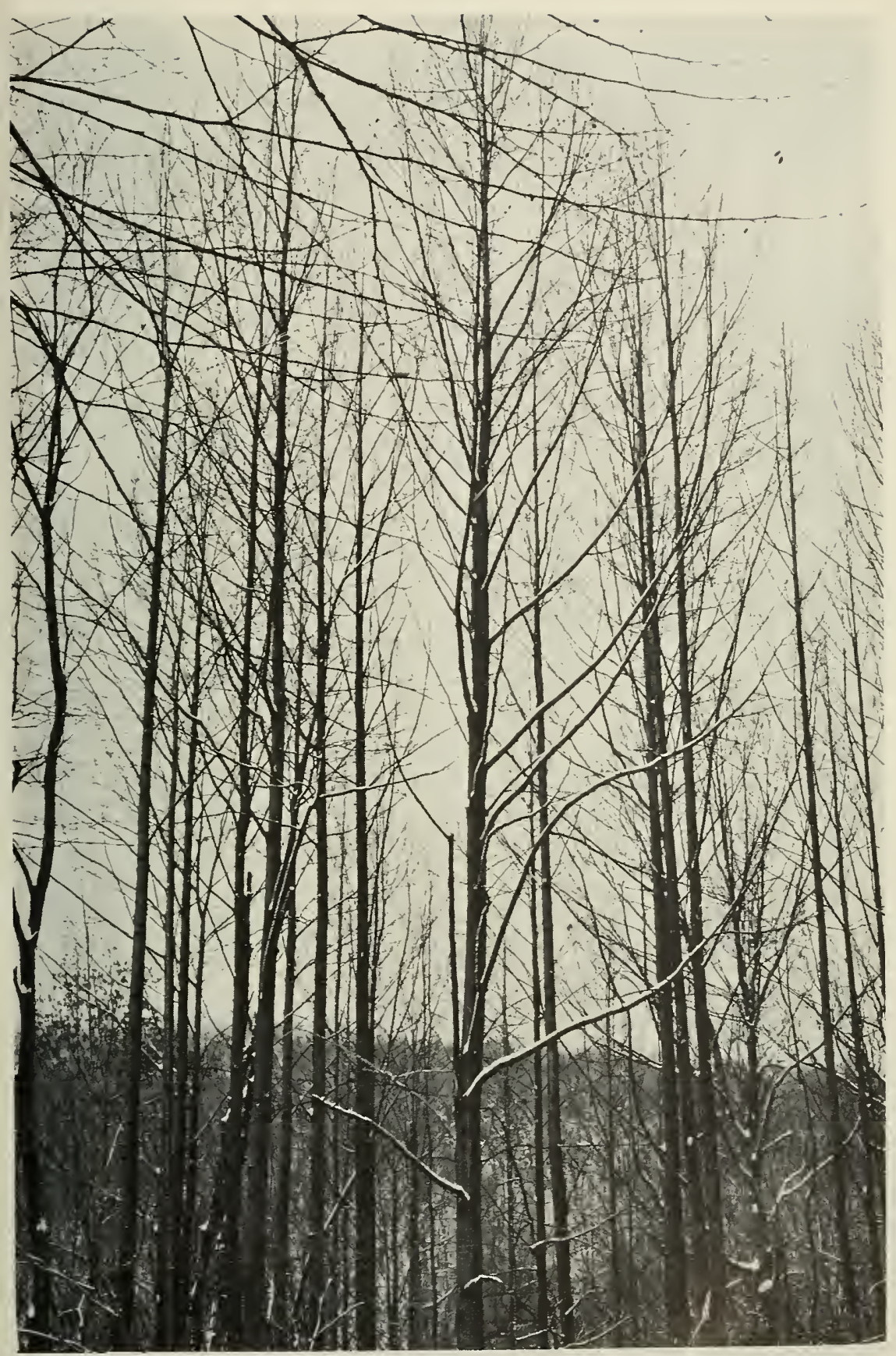

Figure 4-B. Crowns on the control were restricted in development due to the extreme density of the stand. 
TABLE 1

Number of Trees Per Acre and Stand Composition for the Plot Receiving Three Improvement Cuttings During the Period 1949-1960

\begin{tabular}{lccccccc}
\hline \hline & \multicolumn{2}{c}{1949} & \multicolumn{2}{c}{1955} & \multicolumn{2}{c}{1960} & Change \\
\cline { 2 - 7 } & $\begin{array}{c}\text { Before } \\
\text { Cut }\end{array}$ & $\begin{array}{c}\text { After } \\
\text { Cut }\end{array}$ & $\begin{array}{c}\text { Before } \\
\text { Cut }\end{array}$ & $\begin{array}{c}\text { After } \\
\text { Cut }\end{array}$ & $\begin{array}{c}\text { Before } \\
\text { Cut }\end{array}$ & $\begin{array}{c}\text { After } \\
\text { Cut }\end{array}$ & $\begin{array}{c}\text { 1949- } \\
1960\end{array}$ \\
\hline Number of trees & 751 & 620 & $590^{\prime}$ & 455 & $385^{2}$ & 297 & -454 \\
\hline Per cent of trees cut & 17.4 & \multicolumn{2}{c}{22.9} & 22.9 & \\
\hline
\end{tabular}

Number of trees remaining by species

\begin{tabular}{lrrrrrrr}
\hline Yellow-poplar & 277 & 222 & 222 & 182 & 163 & 124 & -153 \\
White oak & 31 & 30 & 27 & 24 & 22 & 22 & -9 \\
N. red and black oak & 193 & 168 & 160 & 118 & 81 & 65 & -128 \\
Red maple & 75 & 55 & 53 & 37 & 37 & 27 & -48 \\
Sugar maple.----- & 54 & 45 & 44 & 35 & 35 & 24 & -30 \\
Black cherry & 37 & 27 & 16 & 11 & 8 & 2 & -35 \\
Others $^{5}$ & 84 & 73 & 68 & 48 & 39 & 33 & -51 \\
\hline
\end{tabular}

TABLE 2

Number of Trees Per Acre and Mortality and Changes in Stand Composition for the Control Plot During the Period 1949-1960

\begin{tabular}{|c|c|c|c|c|}
\hline & 1949 & 1955 & 1960 & $\begin{array}{c}\text { Change } \\
1949-1960 \\
\end{array}$ \\
\hline Number of trees & 836 & $761^{3}$ & $589^{4}$ & -247 \\
\hline \multicolumn{5}{|l|}{$\begin{array}{l}\text { Number of trees remaining } \\
\text { by species }\end{array}$} \\
\hline Yellow-poplar & 185 & 183 & 161 & -24 \\
\hline White oak & 67 & 60 & 43 & -24 \\
\hline N. red and black oak & 196 & 171 & 79 & -117 \\
\hline Red maple & 176 & 169 & 150 & -26 \\
\hline Sugar maple & 4 & 4 & 4 & -0 \\
\hline Black cherry & 15 & 15 & 11 & -4 \\
\hline Others $^{5}$ & 193 & 159 & 141 & -52 \\
\hline
\end{tabular}

1 Mortality between cuttings- 30 .

2 Mortality between cuttings-70.

3 Mortality between measurements -75 .

4 Mortality between measurements- 172 .

5 Others is made up primarily of sassafras and black locust, but included in this grouping are a few stems of cucumbertree, scarlet oak, chestnut oak, butternut, dogwood, blackgum, bigtooth aspen, and black birch. 
TABLE 3

Composition of the 100 Trees Per Acre With the Largest Diameters for the Treated Plot and the Control

\begin{tabular}{lcc}
\hline \multicolumn{1}{c}{ Species } & Treated Plot & Control \\
\hline Yellow-poplar & 94 & 76 \\
Red maple & 4 & 6 \\
Cucumbertree & 2 & 8 \\
Northern red oak & 0 & 4 \\
Black cherry & 0 & 4 \\
Bigtooth aspen & 0 & 2 \\
$\quad$ Total & 100 & 100 \\
\hline
\end{tabular}

TABLE 4

Average Diameter Breast High (All Trees) Before and After Cutting for the Period 1949-1960

\begin{tabular}{lcc}
\hline \hline & \multicolumn{2}{c}{ Diameter Breast High (Inches) } \\
\cline { 2 - 3 } & Treated Plot & Control \\
\hline Before 1949 cutting & 3.1 & 3.1 \\
After 1949 cutting & 3.0 & $\cdots$ \\
Before 1955 cutting & 4.7 & 4.5 \\
After 1955 cutting & 4.6 & $\cdots$ \\
Before 1960 cutting & 6.0 & 5.2 \\
After 1960 cutting & 6.0 & $\cdots$ \\
\hline
\end{tabular}

\section{Discussion}

In each marking on the treated plot an attempt was made to release the crowns of the largest trees by cutting other large trees, adjacent to them, that were of less valuable species or of poor condition. In addition, small merchantable trees were cut, when it was presumed that they would not live until the next cutting. Although no attempt was made to remove a definite per cent of the trees in the stand in each cutting, it is interesting to note that each of the cuts removed about 20 per cent of the stems (Table 1). If four additional improvement cuttings are anticipated prior to the final cutting, this will apparently represent a suitable intensity of removal to leave approximately 100 crop trees per acre at stand maturity.

The high mortality between cuttings may raise some questions, as theoretically, if a cutting is made with suitable intensity and skill, little 
TABLE 5

Basal Area Per Acre Before and After Cutting for the Period 1949-1960

\begin{tabular}{|c|c|c|}
\hline & $\begin{array}{l}\text { Treated Plot } \\
\text { (Sq. Ft.) }\end{array}$ & $\begin{array}{c}\text { Control } \\
\text { (Sq. Ft.) }\end{array}$ \\
\hline Before 1949 cutting & 39.309 & 43.163 \\
\hline Removed in 1949 cutting & 8.514 & \\
\hline After 1949 cutting & 30.795 & 43.163 \\
\hline Increase, 1949-1955 & 39.883 & 39.990 \\
\hline Before 1955 cutting & 70.678 & 83.153 \\
\hline Removed in 1955 cutting & 18.081 & \\
\hline After 1955 cutting & 52.597 & 83.153 \\
\hline Increase, 1955-1960 & 22.997 & 2.438 \\
\hline Before 1960 cutting & 75.594 & 85.591 \\
\hline Removed in 1960 cutting & 17.960 & \\
\hline After 1960 cutting & 57.634 & 85.591 \\
\hline
\end{tabular}

TABLE 6

Merchantable Cord Volume Per Acre Before and After Cutting FOR THE PERIOD 1949-1960

\begin{tabular}{|c|c|c|}
\hline & $\begin{array}{c}\text { Treated Plot } \\
\text { (Cords) }\end{array}$ & $\begin{array}{l}\text { Control } \\
\text { (Cords) }\end{array}$ \\
\hline Before 1949 cutting & 5.02 & 4.24 \\
\hline Removed in 1949 cutting & $0.04 *$ & ----- \\
\hline After 1949 cutting & 4.98 & 4.24 \\
\hline Increase, 1949-1955 & 9.43 & 8.63 \\
\hline Before 1955 cutting & 14.41 & 12.87 \\
\hline Removed in 1955 cutting & 3.37 & $\cdots--$ \\
\hline After 1955 cutting & 11.04 & 12.87 \\
\hline Increase, 1955-1960 & 7.10 & 1.73 \\
\hline Before 1960 cutting & 18.14 & 14.60 \\
\hline Removed in 1960 cutting & 4.38 & ----- \\
\hline After 1960 cutting & 13.76 & 14.60 \\
\hline Removed in cuttings, 1949-1960 & 7.79 & $-\ldots$ \\
\hline
\end{tabular}


or no mortality should occur between cuts (Table 1). On examining the individual tree records, it was discovered that this mortality occurred entirely in unmerchantable trees, those that were too small to be removed in the improvement cuttings. This was not true of the mortality on the control. On both plots many of the smaller trees will continue to grow slowly to merchantable size. On the treated plot these will be removed gradually in later improvement cuttings; however, it is expected that some mortality will continue, but at a decreasing rate, throughout the rotation. It is of interest that the major portion of this loss on both plots is in the shaded trees of the light-demanding species, northern red oak, white oak, black oak, black cherry, sassafras, black locust, bigtooth aspen, and yellow-poplar (Table 1).

If the reduction in the number of yellow-poplar for the treated plot and the control is compared (Tables 1 and 2), it first appears that many more yellow-poplar were removed from the treated plot than seems justified. The reason for this is the intentional removal of poorlyformed poplars from the main crown canopy to give adequate space for crown expansion of the best trees.

Wherever possible northern red oak and black oak were favored over white oak. In this locality white oak grows more slowly than red and black oak, yet brings no higher stumpage price than other oaks. On very favorable sites, and particularly where limestone soils occur, white oak grows more rapidly and produces higher quality wood than it does in this section of West Virginia. In those localities high stumpage prices often are obtained, particularly when the trees are of veneer or cooperage quality. The relative worth of northern red and black oak versus white oak must be evaluated for each section of this State and for each site to determine the proper order of preference.

Regardless of the site quality, black cherry of good stem form and condition should be favored above all other native hardwoods except black walnut because of its extremely high stumpage value. Unfortunately, much of the young black cherry is of poor form, limby, and diseased. The heavy removal of cherry in the improvement cuttings (Table 1) is due to the poor condition of these trees. Much thought and careful examination must be used in marking black cherry, since even trees of average quality (Figure 6) on maturity are worth far more than high-quality trees of many other native hardwoods (Carvell and Koch, 1963).

Examination of Table 3 suggests that the marking was intended to convert the stand to yellow-poplar. Actually in cove hardwood mixtures this is often the best policy, leaving good trees of cucumbertree, sugar maple, and black cherry, where they occur. Yellow-poplar and these associates grow rapidly and produce straight, well-pruned boles, which 


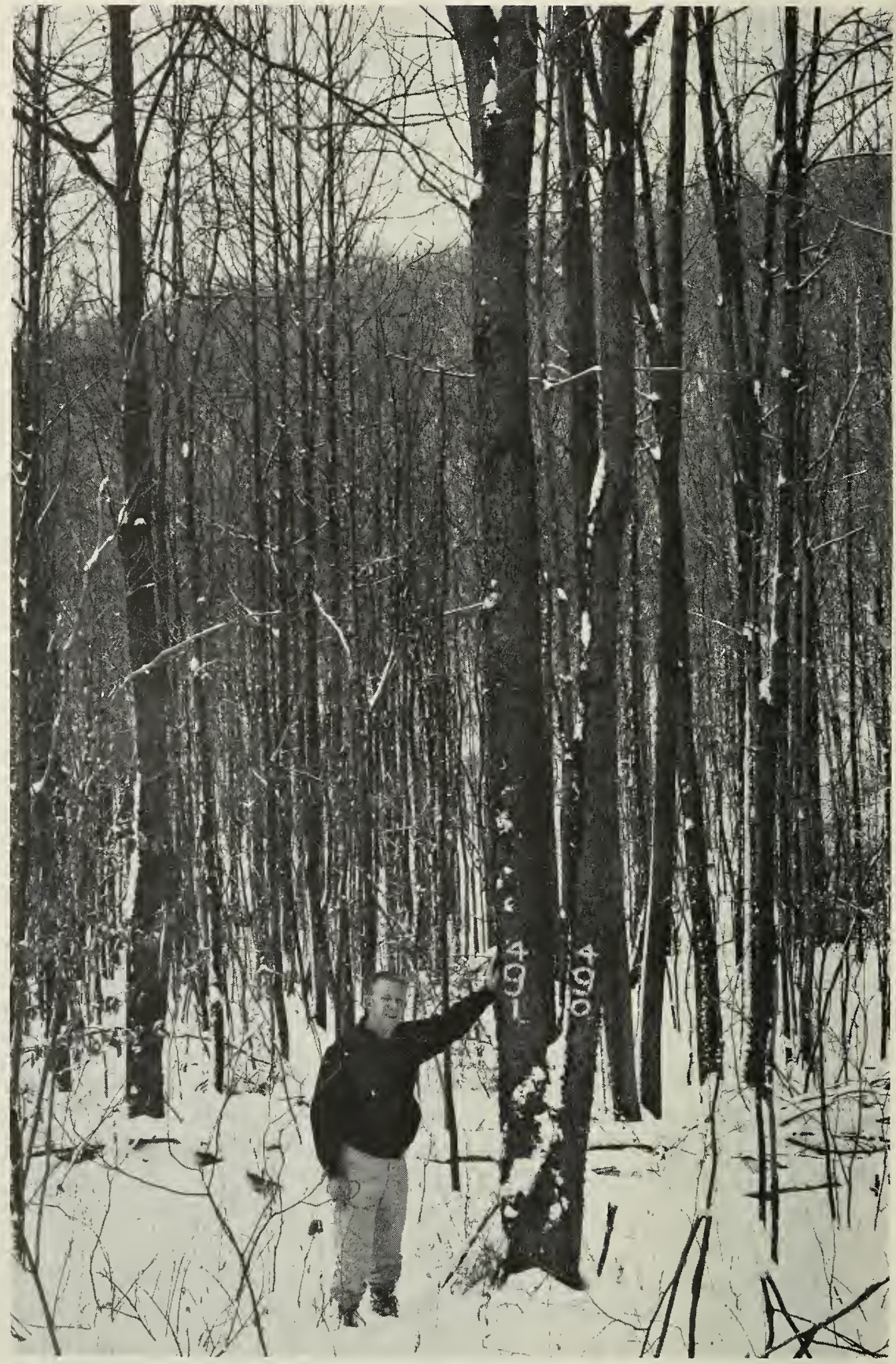

Figure 5. Twin black cherries of average quality. Cherry should be favored wherever possible because of its high stumpage value. 
command a higher stumpage price than most other species in this forest type.

Diameter growth on the treated plot is gradually forging ahead of the control (Table 4). The d.b.h. before and after the 1949 and 1955 cuttings indicate that the greatest number of cut stems were larger than the average diameter, thus decreasing the average diameter after cutting. In the 1960 cutting the trees removed were about equally distributed around the average diameter, making no measurable change in the average d.b.h. after cutting.

Examination of the basal area figures indicates a rapid increase in the basal area after each cutting (Table 5). An interesting comparison can be made between the two plots for the increase between 1955 and 1960. Basal area increase on the control plot appears to have fallen off, with only 2.438 square-foot per acre gain during the five-year period, compared with an increase of 22.997 square feet on the treated plot. Actually the 2.438 figure does not present a true picture because of the large mortality on this plot (172 stems) during that period. However, the small net increase in basal area on the control is a definite sign of overcrowding, and, combined with our knowledge of mortality during the 1955-1960 period, emphasizes the need and benefits of improvement cuttings.

The merchantable cord volume (Table 6) presents the most vivid picture of what actually happened on these plots during the 15-year period. After the 1960 cutting, the volume on these plots was comparable, yet nearly eight cords of saleable material had been removed from the treated plot. Much of the cord volume from the control, which could have been sold, actually died and rotted on the ground. Nature thinned the control, selecting the trees to survive without any regard to future marketable value.

If the material marked in these partial cuttings had been sold as stumpage for hardwood pulpwood, the income obtained per acre for improving these stands would have been between $\$ 1.50$ and $\$ 2.00$ per cord. This would have yielded a total income for the three improvement cuttings of from $\$ 11.51$ to $\$ 15.83$. Although this figure is not spectacular, when considered in addition to the increased future stand value, it should seem profitable.

\section{Summary}

A series of three improvement cuttings was made over an 11-year period on a 0.9 acre experimental plot on a cove hardwood site in northern West Virginia. These cuttings were designed to measure the effects of improvement cuttings on immature hardwood stands. The 


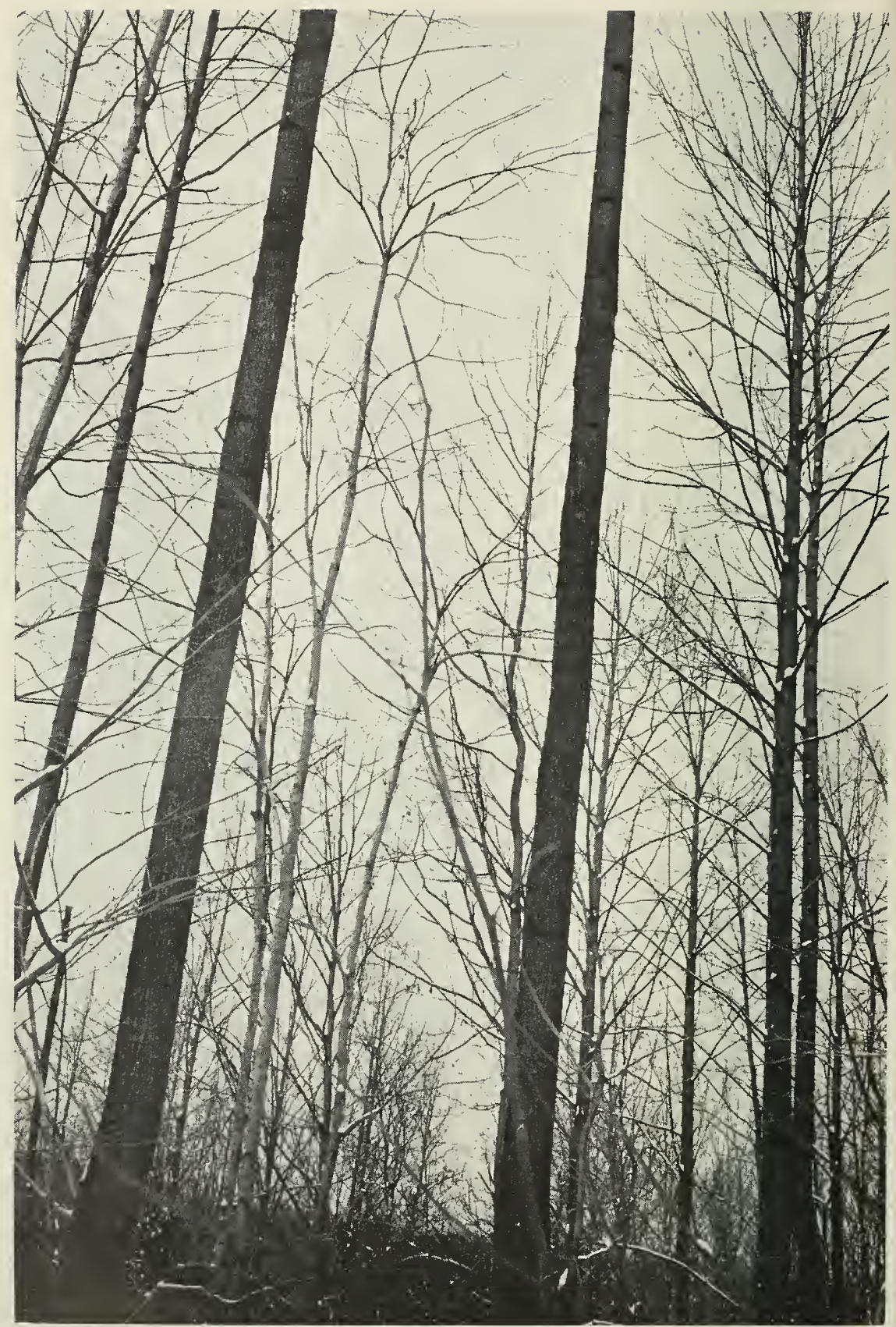

Figure 6. After three cultings only the straightest stems were left on the treated plot. The one hundred largest trees were all of potential sautimber quality. 
resulting data are compared with those from an adjacent untreated plot, used as a control.

After these cuttings, 354 trees per acre had been cut and sold. These cuttings left the straightest yellow-poplar dominating the stand. The number of red maple and poorly-formed oaks and black cherry was greatly reduced through cutting and through natural mortality between treatments.

The average diameter of all trees on the treated plot increased 2.9 inches during the 11-year period, while that of the control increased only 2.1 inches.

In the three improvement cuttings a total of 7.8 cords was removed per acre. In spite of this drain, the standing cord volume at the end of the 11-year period was nearly similar on both plots.

A total income for the three improvement cuttings would vary from $\$ 11.00$ to $\$ 15.00$ per acre, depending on local market conditions. Although this return is not spectacular, when combined with the increased future value of the stand, it should seem a profitable practice on forest land supporting cove hardwood stands.

As the markets for hardwood pulpwood and charcoal wood expand in this State, stumpage prices will undoubtedly rise, and the attractiveness and use of improvement cuttings should increase rapidly.

\section{LITERATURE GITED}

Besley, L. 1941. Practical forest management for the cut-over hardwood lands in southern West Virginia. W. Va. Univ. Agr. Expt. Sta. Bull. 300. 15, xlvi p.

Carvell, K. L. and C. B. Koch. 1963. Black cherry-its abundance, quality, and rate of growth in the oak-hickory and cove forests of West Virginia. W. Va. Univ. Agr. Expt. Sta. Bull. 485.12 p.

Roth, E. R. and B. Sleeth. 1939. Butt rot in unburned sprout oak stands. U. S. Dept Agr. Tech. Bull. 684. 4.3 p. 


